\title{
Urethral Cancer pTis TNM Finding v7
}

National Cancer Institute

\section{Source}

National Cancer Institute. Urethral Cancer pT is TNM Finding v7. NCI Thesaurus. Code C89373.

Urethral cancer with a finding of carcinoma in situ. (from AJCC 7th Ed.) 